\title{
Role of Rho/ROCK signaling in the interaction of melanoma cells with the blood-brain barrier
}

\author{
Imola Wilhelm ${ }^{1 *}$, Csilla Fazakas ${ }^{1 *}$, Judit Molnár ${ }^{1}$, János Haskó ${ }^{1}$, Attila G. Végh ${ }^{1}$, László Cervenak ${ }^{2}$, \\ Péter Nagyőszi ${ }^{1}$, Ádám Nyúl-Tóth ${ }^{1}$, Attila E. Farkas ${ }^{1}$, Hannelore Bauer ${ }^{3}$, Gilles J. Guillemin ${ }^{4}$, \\ Hans-Christian Bauer ${ }^{3,5}$, György Váró ${ }^{1}$ and István A. Krizbai ${ }^{1}$ \\ 1 Institute of Biophysics, Biological Research Centre, Hungarian Academy of Sciences, Szeged, Hungary \\ 2 Department of Medicine, Semmelweis University, Budapest, Hungary 3 Department of Organismic Biology, \\ University of Salzburg, Salzburg, Austria 4 MND and Neurodegenerative Diseases Research Centre, Macquarie \\ University, Sydney, NSW, Australia 5 Paracelsus Private Medical University (PMU), Salzburg, Austria \\ CORRESPONDENCE István A. Krizbai, e-mail: krizbai.istvan@brc.mta.hu \\ *I.W. and C.F. contributed equally to this work and both should be considered as first authors \\ KEYWORDS blood-brain barrier/cerebral endothe- \\ lial cell/melanoma/metastasis/Rho/ROCK \\ PUBLICATION DATA Received 8 February 2013, \\ revised and accepted for publication 16 September \\ 1 2013, published online xxxx \\ doi: $10.1111 /$ pcmr.12169
}

\section{Summary}

We have investigated the role of the Rho/ROCK signaling pathway in the interaction of metastatic melanoma cells with the brain endothelium. ROCK inhibition induced a shift of melanoma cells to the mesenchymal phenotype, increased the number of melanoma cells attached to the brain endothelium, and strengthened the adhesion force between melanoma and endothelial cells. Inhibition of ROCK raised the number of melanoma cells migrating through the brain endothelial monolayer and promoted the formation of parenchymal brain metastases in vivo. We have shown that inhibition of the Rho/ROCK pathway in melanoma, but not in brain endothelial cells, is responsible for this phenomenon. Our results indicate that the mesenchymal type of tumor cell movement is primordial in the transmigration of melanoma cells through the blood-brain barrier.

\section{Introduction}

Brain tumors are life-threatening pathologies with limited therapeutic options, representing a major cause of death in patients with cancer. The majority of the tumors of the central nervous system (CNS) are metastases, among which lung cancer, breast cancer, and melanoma are the most common. Melanoma has an unexpectedly high affinity to the brain, the prevalence of brain metastases being 55-75\% in patients with melanoma. Unfortunately, present treatment strategies of melanoma brain metastases are very ineffective, the prognosis of the disease is extremely poor: The median survival of the patients is
$<1$ yr (reviewed in: Chen and Davies (2012)). Therefore, development of strategies aiming to prevent the dissemination of melanoma cells into the CNS is urgently needed. This requires understanding of the mechanisms of melanoma brain metastasis formation, in particular identification of key pathways and molecules involved in the interplay between melanoma cells and cells of the CNS.

The first host cell type encountered by circulating cancer cells during brain metastasis formation is endothelial cells of the brain vasculature. Cerebral endothelial cells (CECs) have a highly differentiated phenotype, induced and maintained by the cross-talk with the

\section{Significance}

The first host cells encountered by melanoma cells during brain metastasis formation are cerebral endothelial cells, which form the morphological basis of the blood-brain barrier (BBB). Despite the undisputable clinical importance, little is known about the mechanisms of extravasation of melanoma cells through the BBB. Our data suggest that the mesenchymal type of tumor cell movement (induced by ROCK inhibition) is more important than the ameboid type during migration of melanoma cells through the brain endothelium. This mechanism might have clinical importance as well, as pharmacological inhibitors of ROCK signaling are emerging as potent therapeutic agents in different pathologies. 
surrounding cells of the neurovascular unit. In this respect, CECs have special epithelial-like features, including the formation of a continuous belt of tight junctions between cells and expression of a special set of transporters and enzymes, which result in the formation of the blood-brain barrier (BBB) (for review see: Abbott et al. (2010); Wilhelm et al. (2011)). Therefore, during extravasation from the blood stream into the brain parenchyma, melanoma cells have to migrate through the BBB. Nevertheless, the interactions between melanoma cells and endothelium of the CNS are still largely uncharacterized (reviewed in: Wilhelm et al. (2013)).

Rho-kinases (ROCK1 and ROCK2) are the main effectors of the small GTPase RhoA and RhoC, having several substrates (including the LIM-kinases and myosin light chain) involved in the regulation of the cytoskeleton. Accordingly, the Rho/ROCK pathway plays important roles in a wide range of cellular phenomena, such as contractility, motility, cell cycle, apoptosis, or intercellular adhesion.

Rho/ROCK signaling was shown to be involved in the ameboid invasion phenotype of cancer cells, which is characterized by rounded morphology and increased actomyosin contractility. Nevertheless, tumor cells are able to switch between the ameboid and mesenchymal type of cell movement, and this latter displaying an elongated morphology, extracellular proteolysis, and activation of the small GTPase Rac (Sahai and Marshall, 2003; Sanz-Moreno et al., 2008; Wolf et al., 2003). It is not surprising that studies regarding the effects of ROCK inhibition on tumor cell motility, invasion, and metastasis formation are contradictory and appear to depend on the tumor cell type. Inhibition of ROCKs has been shown to decrease the invasion and migration of lung (Yang et al., 2010, 2012; Zhu et al., 2011), breast (Wyckoff et al., 2006), and hepatocellular carcinoma cells (Chen et al., 2011; Itoh et al., 1999; Ying et al., 2006). In contrast, in case of osteosarcoma (Yui et al., 2010), pancreatic carcinoma (Fujita et al., 2011), colon carcinoma (Adachi et al., 2011; Vishnubhotla et al., 2012), and scirrhous gastric carcinoma (Matsuoka et al., 2011), ROCK inhibitors promoted invasive and migratory properties of the cells. Regarding melanoma, inhibition of the Rho/ROCK signaling system was shown to alter the expression of tumor progression genes (Spencer et al., 2011), reduce proliferation (Routhier et al., 2010), cell invasion, and formation of lung metastases (Kidera et al., 2010).

In addition, movement of tumor cells might also depend on the physicochemical and biological properties of the extracellular matrix or endothelial barrier they need to cross. For example, a thick soft three-dimensional substratum was shown to favor ameboid type of tumor cell migration, while cells with mesenchymal phenotype prefer a firm two-dimensional substratum (Symons and Segall, 2009). Moreover, the Rho/ROCK pathway in both the tumor and endothelial cells is likely to play a role in the transendothelial migration. Therefore, ROCK inhibitors might influence (additively or oppositely) this process from the side of both cell types.

Considering the controversial role of Rho/ROCK signaling in cancer biology, and the clinical importance of melanoma brain metastases, we have investigated the potential role of the Rho/ROCK pathway in the interaction of melanoma and cerebral endothelial cells.

\section{Results}

\section{Role of Rho-kinases in the adhesion and morphological properties of melanoma cells}

To clarify the role of Rho/ROCK signaling in the formation of brain metastases, we investigated the effect of the inhibition of ROCK on the attachment of melanoma cells to monolayers of cerebral endothelial cells. A2058 melanoma cells were seeded onto hCMEC/D3 (D3) endothelial monolayers in the presence or absence of $10 \mu \mathrm{M}$ Y27632 for 90 min. Inhibition of ROCK led to a significant increase in the number of melanoma cells attached to the endothelium (Figure $1 \mathrm{~A})$. In the absence of the endothelial monolayer, the Y27632-induced increase in the number of A2058 cells attached to collagen was also significant, but less pronounced. Similar changes were observed using B16/ F10 melanoma cells.

In control conditions, the ratio of elongated versus rounded melanoma cells attached to the endothelium was 1.33, while in the presence of Y27632, a significant shift to the elongated morphology was observed (Figure 1A). Accordingly, Y27632 induced a significant increase in the average area of melanoma cells attached to the brain endothelium (Figure 1B). Consequently, the total area of the endothelial monolayer covered by melanoma cells increased by approximately 4.5-fold in the presence of $Y 27632$.

Attachment of melanoma cells to the brain endothelium was also potentiated by another ROCK inhibitor, fasudil, while the Rac inhibitor EHT1864 was able to parry the effects of Y27632 on the attachment of melanoma cells (Figure 2).

To investigate the morphological changes induced by ROCK inhibition, melanoma cells were seeded onto collagen-coated coverslips in the presence or absence of Y27632. At 90 min after plating, the majority of both types of melanoma cells had a rounded morphology with several membrane blebs. Inhibition of ROCK resulted in a switch to an elongated, fibroblastoid cell morphology with large actin-rich protrusions, and several filopodia (Figure 3A). Moreover, the ROCK inhibitor Y27632 increased the proteolytic activity of melanoma cells, which was abolished by the Rac inhibitor EHT1864 (Figure 3B). These suggest that inhibition of ROCK induces a shift of melanoma cells to the mesenchymal type of morphology. 

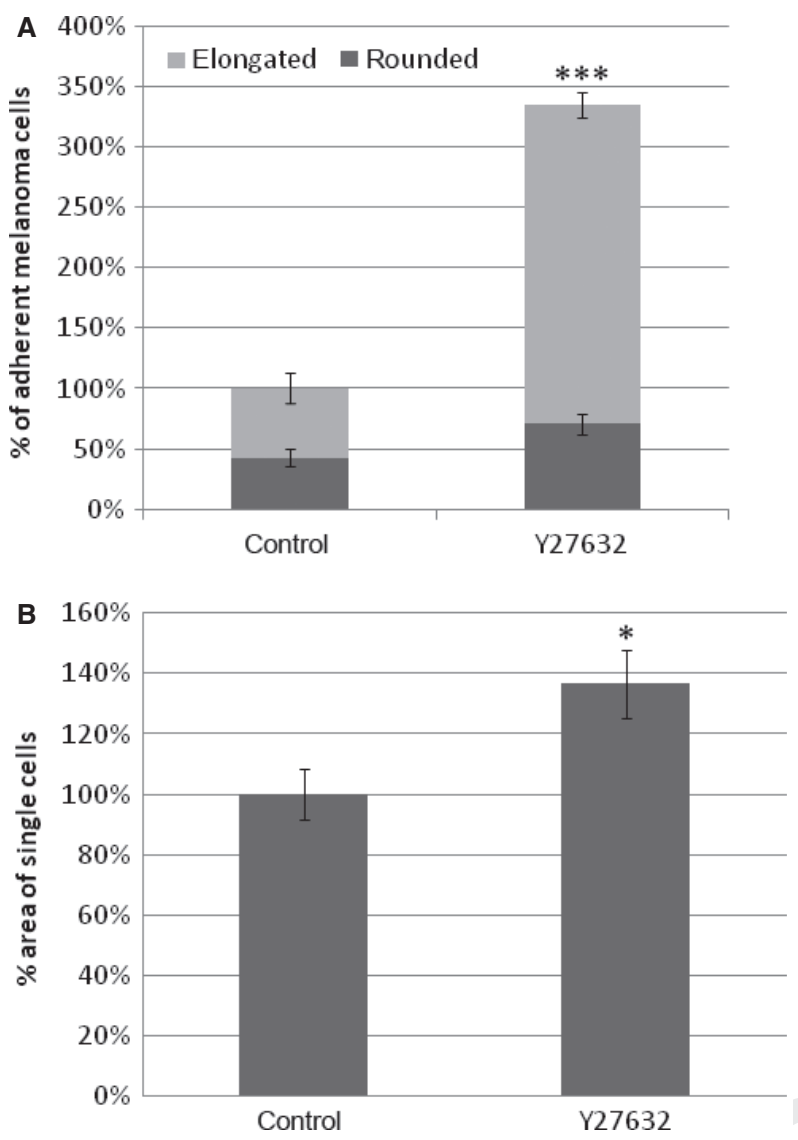

Figure 1. Attachment of melanoma cells to brain endothelial cells in $\mathbf{2 5}$ the presence and absence of Y27632. Fluorescently labeled A2058 melanoma cells were plated onto confluent D3 monolayers and left for 90 min. After washing of non-adherent cells, attached melanoma cells were counted. (A) Average area of single melanoma cells attached to the brain endothelium was measured using the IMAGE PROPLUS software. (B) Results are expressed as, \% control and given as mean $\pm \mathrm{SD}$. $\mathrm{N}=3, * * *=\mathrm{P}<0.0005, *=\mathrm{P}<0.05$ as assessed by Student's t-test.

\section{Effect of Y27632 on the adhesion forces between melanoma cells and endothelial cells}

As a next step, we investigated whether the increased number of attached melanoma cells to the endothelium correlates with an increase in the adhesion forces between individual melanoma cells and endothelial cells. We attached melanoma cells to functionalized tipless AFM cantilevers and quantified the total unbinding force (adhesion) between the melanoma cell and endothelial cells. When a loading force of $2 \mathrm{nN}$ was applied the total adhesion force was of $200 \mathrm{pN}$ in control conditions. We found that inhibition of ROCK led to an increase in the total unbinding force between melanoma and endothelial cells, reaching an approximately 2.5 -fold value after $45 \mathrm{~min}$ (Figure 4A). Initially, the size and later the number of individual unbinding events seemed to increase (Figure 4B, C).

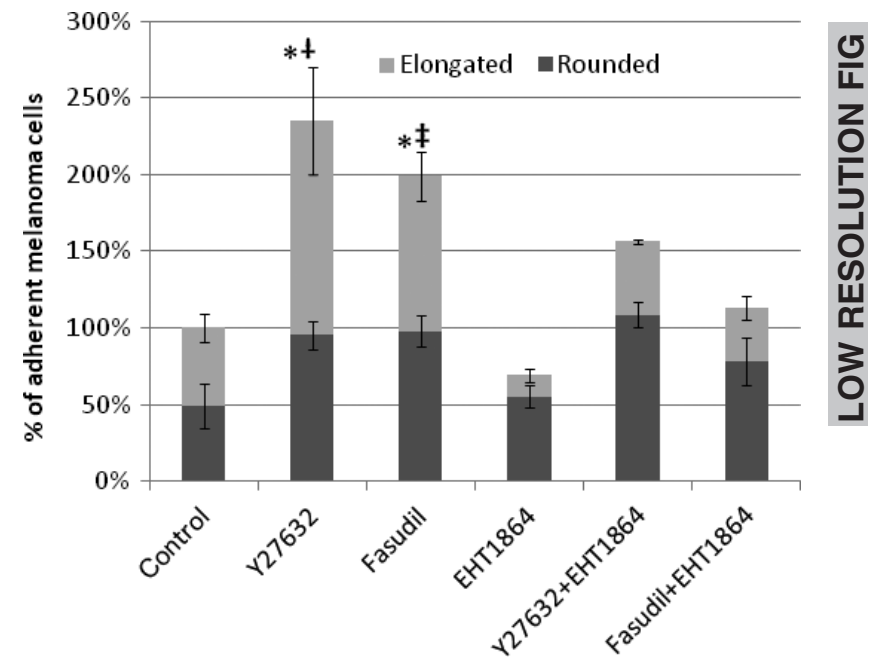

Figure 2. Attachment of melanoma cells to brain endothelial cells in $\mathbf{2 6}$ the presence and absence of Y27632, fasudil, and EHT1864. Fluorescently labeled A2058 melanoma cells were plated onto confluent D3 monolayers and left for 90 min. After washing of nonadherent cells, attached melanoma cells were counted. Results are expressed as, \% control and given as mean \pm SD. $N=3$,

$*=\mathrm{P}<0.05$ compared with control, $\dagger=\mathrm{P}<0.05$ compared with Y27632 + EHT1864-treated cells and $\ddagger=P<0.05$ compared with fasudil + EHT1864-treated cells, as assessed by ANOVA and Bonferroni's post hoc test.

\section{Role of adhesion molecules in the interaction of melanoma and brain endothelial cells}

The pronounced increase in the number of melanoma cells attaching to the brain endothelium and the significant increase in the adhesion forces between the two cell types prompted us to test the changes in the expression of adhesion molecules in the presence of Y27632. The expression of integrin subunits and MCAM in melanoma cells was assessed using real-time PCR. No difference in the mRNA expression of integrin $\alpha_{M}, \alpha_{v}$, $\alpha_{4}, \beta_{1}, \beta_{2}, \beta_{3}$, and MCAM was observed between control and Y27632-treated A2058 cells (Figure S1A). The $\alpha_{L}$ subunit was not expressed. Expression of $\mathrm{N}$ cadherin was tested using Western blot in A2058 and B16/F10 melanoma cells. No change in the expression of $\mathrm{N}$-cadherin was seen after Y27632 treatment (Figure S1B).

Expression and localization of ICAM-1, ICAM-2, VCAM1, PECAM-1, and CD99 in brain endothelial cells were analyzed by immunofluorescence staining. ICAM-1, VCAM-1, and E-selectin were not significantly expressed in control brain endothelial cells, but could be induced by TNF- $\alpha$ or LPS treatment. However, neither Y27632, A2058, nor A2058-conditioned medium induced the expression of ICAM-1, VCAM-1, or E-selectin. ICAM-2, PECAM-1, and CD99 were present on control endothelial cells; however, their expression was not significantly influenced by Y27632 treatment, addition of A2058 cells or A2058-conditioned medium (Figure S2). 

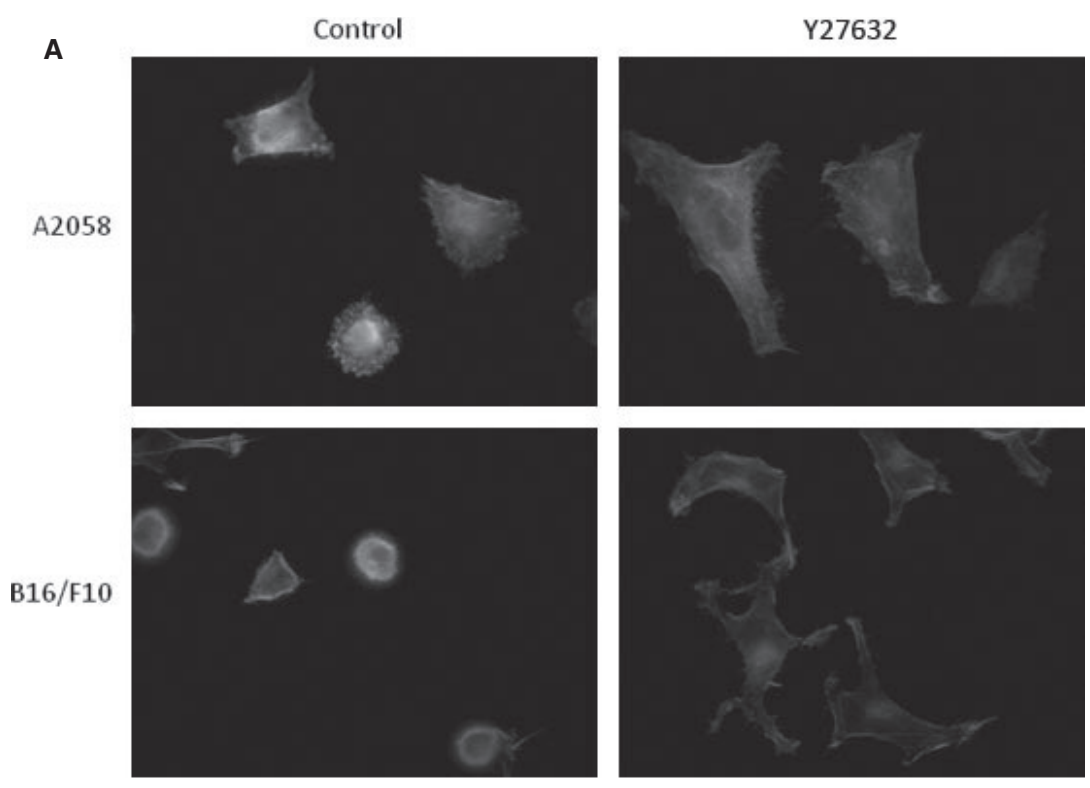

Figure 3. Effect of Y27632 on the morphology and protease activity of melanoma cells. (A) A2058 or B16/F10 melanoma cells were seeded onto collagen-coated surfaces in the presence or absence of $10 \mu \mathrm{M}$ Y27632. After 90 min,

D3 D3+A2058

B

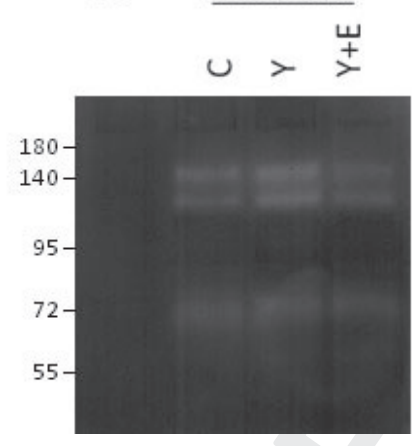
cells were fixed and stained with Alexa488labeled phalloidin. (B) A2058 melanoma cells were preteated for 90 min with Y27632 or Y27632 and EHT1864, then plated onto confluent monolayers of D3 cerebral endothelial cells in serum-free medium and left for 5 h. Cells were lysed in Triton X-114 containing buffer. Samples were electrophoresed in non-denaturing conditions, and the gels were incubated in EDTA-containing buffer for 2 days.

Proteolytic bands of culture media were visualized by Coomassie blue staining.
We have also tested the effect of heparin - an inhibitor of selectin- and integrin-mediated cell-cell interaction - on the Y-27632-induced adhesion of melanoma cells to CECs. In control conditions (i.e. when no Y27632 was added), pretreatment with heparin of either melanoma or endothelial cells had no significant effect on the number of attached cells after $90 \mathrm{~min}$. Pretreatment of melanoma cells with heparin did not influence the Y-27632-enhanced adhesion of melanoma cells. However, pretreatment of endothelial cells reduced the number of attached melanoma cells to the control level (Figure 5).

\section{Effect of ROCK inhibition on the transmigration of melanoma cells through CECs}

To test whether the increase in the number of melanoma cells attached to the endothelium is accompanied by an increase in the number of transmigrating melanoma cells, we cultured cerebral endothelial cells on filter inserts with pore size of $8 \mu \mathrm{m}$ to allow migratory cells to reach the bottom of the filter. In response to ROCK inhibition, the number of melanoma cells performing transendothelial migration increased significantly by 2.75 - or 2.11 -fold in case of A2058 melanoma cells treated with Y27632 and fasudil, respectively, and by 5.60-fold in case of B16/F10 melanoma cells treated with Y27632 (Figure 6). Migration of melanoma cells in the absence of endothelial cells was not affected by Y27632 as assessed by the wound assay (not shown).

\section{Effect of Y27632 on melanoma brain metastasis formation in vivo}

We have studied the role of ROCK inhibition on melanoma brain metastasis formation in vivo as well. We injected B16/F10 melanoma cells into the carotid artery of C57/BL6 mice, some of which were additionally administered $500 \mu \mathrm{g} / \mathrm{kg} \mathrm{Y27632} \mathrm{intravenously.} \mathrm{In} \mathrm{control}$ conditions, B16/F10 was able to form mainly non-parenchymal (meningeal and ventricular) metastases, only $0.67 \pm 0.24$ parenchymal metastasis per mouse could be observed. However, in mice treated with Y27632, the number of parenchymal metastases increased significantly to $3.11 \pm 0.37$ parenchymal metastasis per mouse (Figure 7). 


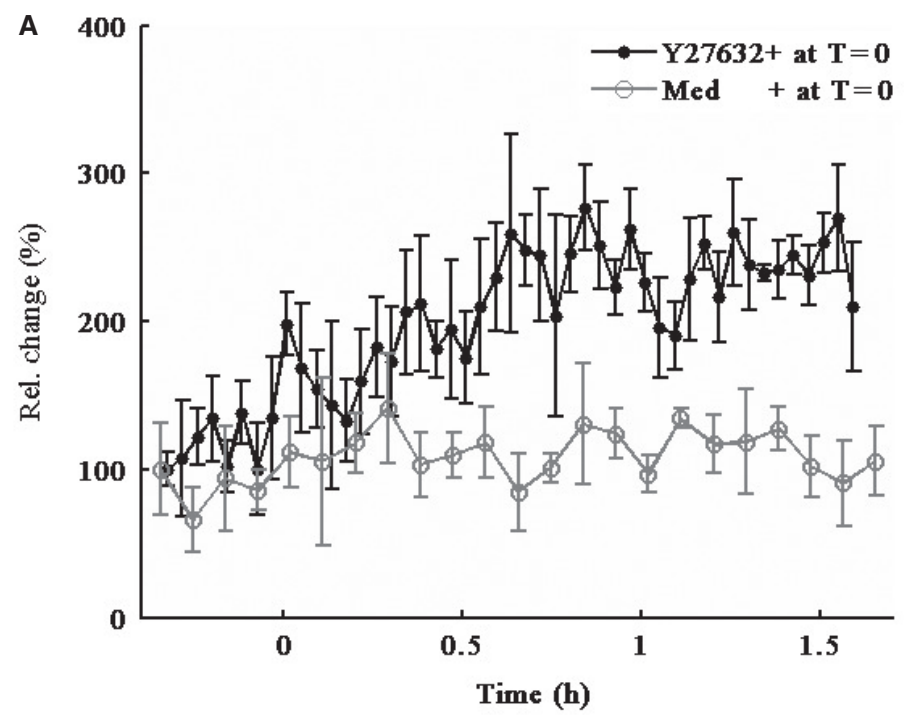

Figure 4. Measurement of melanomaendothelial adhesion force using AFM. Fluorescently labeled A2058 melanoma cells were attached to functionalized tipless AFM cantilevers and pressed against a D3 endothelial layer. The adhesion force was quantified as described in the Methods. At $T=0$, fresh medium was added containing or not $10 \mu \mathrm{M}$ Y27632. (A) total adhesion force, (B) number of ruptures, (C) size of ruptures. Results are expressed as $\%$ control and given as mean $\pm \mathrm{SD}, \mathrm{N}=5$
28

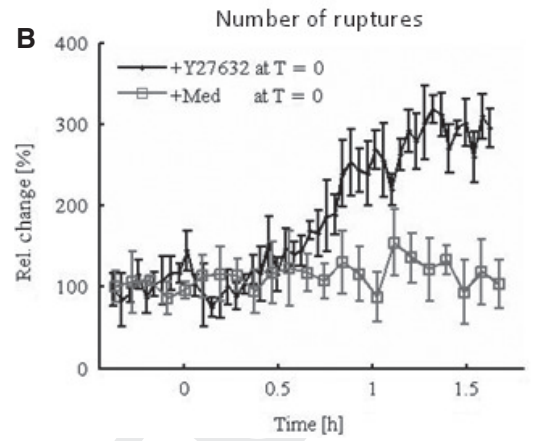

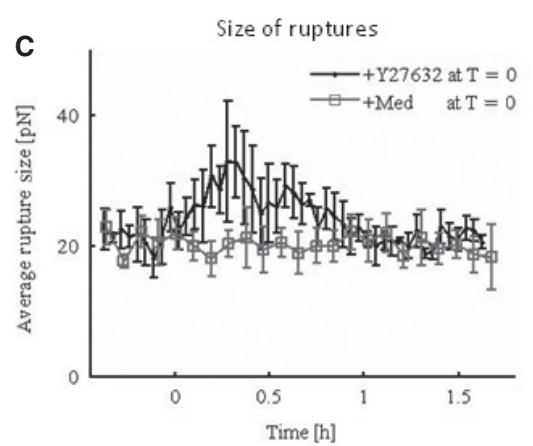

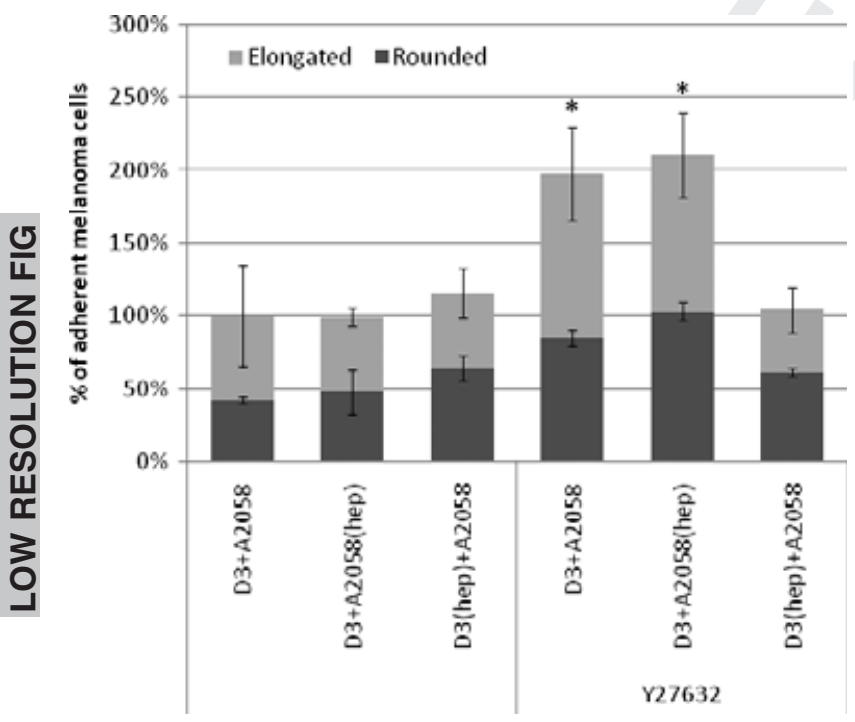

29 Figure 5. Influence of heparin on the attachment of melanoma cells to brain endothelial cells. Fluorescently labeled A2058 melanoma cells were plated onto confluent D3 monolayers and left for $90 \mathrm{~min}$. When indicated, melanoma or endothelial cells were pretreated with $5 \mathrm{mg} / \mathrm{ml}$ heparin for $90 \mathrm{~min}$ (A2058(hep) and D3-(hep), respectively). Results are expressed as \% control and given as mean $\pm \mathrm{SD} . \mathrm{N}=3$, $*=\mathrm{P}<0.05$ compared with control, as assessed by ANOVA and Bonferroni's post hoc test.

\section{Role of melanoma versus endothelial Rho/ROCK signaling in the transendothelial migration of melanoma cells}

As Y27632 and fasudil are reversible inhibitors, we could not use them to differentiate between the role of Rho/ ROCK in endothelial and melanoma cells. Therefore, we pretreated melanoma or endothelial cells with the irreversible Rho inhibitor CTO4 and performed transmigration experiments (Figure 8). Pretreatment of endothelial cells with CTO4 had no effect on the number of melanoma cells migrated through the endothelial monolayer. On the other hand, pretreatment of melanoma cells with CTO4 induced a significant increase in the number of melanoma cells migrating from the apical to the basolateral side of the endothelium. The increase was 1.51-fold in case of A2058 cells and 2.43-fold in case of B16/F10 cells. This suggests that inhibition of the Rho/ROCK pathway in melanoma, but not in brain endothelial cells induces a significant increase in the number of melanoma cells migrating through the endothelium. Moreover, silencing of ROCK-I and ROCK-II genes in melanoma cells significantly increased their adhesion to the brain endothelium (Figure 9), further supporting the role of the Rho/ROCK pathway in melanoma cells in the interaction between melanoma cells and brain endothelial cells. Our results 
A

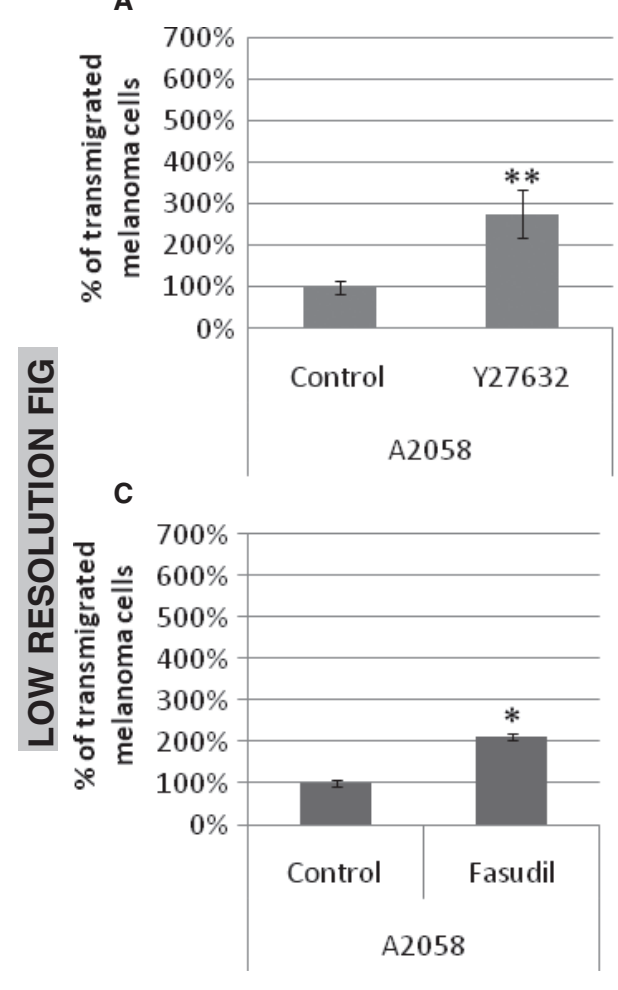

\section{B}

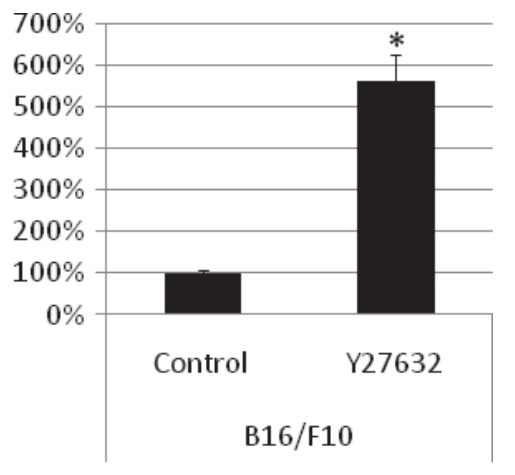

Figure 6. Role of ROCK inhibition in the transendothelial migration of melanoma cells. RBECs were grown until confluency on $8 \mu \mathrm{m}$ pore size filter inserts.

Fluorescently labeled melanoma cells $(A, C)$ A2058, (B) B16/F10 were plated into the upper chamber in the presence or absence of $10 \mu \mathrm{M}$ Y27632 or $10 \mu \mathrm{M}$ fasudil and left for $5 \mathrm{~h}$. Cells from the upper chamber were removed using a cotton swab, and melanoma cells migrated through the endothelial cell layer and the pores of the filter were counted. Results are expressed $\mathrm{as}_{1} \%$ control and given as mean $\pm \mathrm{SD}$. (A) $N=5$, (B) $N=3$, (C) $N=2$,

$* *=\mathrm{P}<0.005 ; *=\mathrm{P}<0.01$ as assessed by Student's $t$-test.
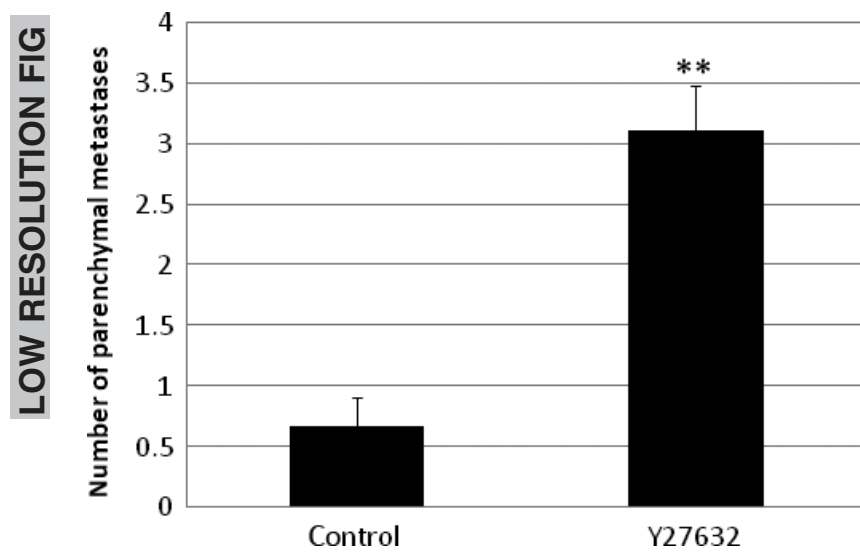

31 Figure 7. Effect of ROCK inhibition on parenchymal brain metastasis formation in vivo. B16/F10 melanoma cells were injected into C57/ BL6 mice. Y27632 was administered intravenously in a dose of $500 \mu \mathrm{g} / \mathrm{kg}$. After 10 days, animals were sacrificed and parenchymal metastases were counted in the brains. Graph represents mean $\pm \mathrm{SEM}, \mathrm{N}=6, * *=\mathrm{P}<0.005$ as assessed by Student's $t$-test.

suggest that inhibition of both ROCK-I and ROCK-II is needed to increase the adhesion of melanoma cells to the brain endothelium, as silencing of either ROCK-I or ROCKII in melanoma cells induced only a slight, non-significant increase in the adhesion rate $(128.5 \pm 16.26 \%$ and $134.00 \pm 19.80 \%$, respectively, compared with control cells).

\section{Discussion}

Transmigration of melanoma cells through the brain endothelium is a fundamental step in the formation of brain metastases. Clarification of key mechanisms involved in this process is of great importance. Here, we have investigated the involvement of Rho/ROCK in this phenomenon.

When inhibiting the Rho/ROCK pathway, the mesenchymal phenotype is induced which consists of an elongated, fibroblastoid cell morphology with large actinrich protrusions and several filopodia, with increased capacity of the cells to adhere to collagen and even more to endothelial cells. Mesenchymal motility is dependent on extracellular proteolysis. Previously, we and others have shown that melanoma cells coming in contact with brain endothelial cells are induced to release proteases (Fazakas et al., 2011; Perides et al., 2006). We have shown that melanoma cells coming in contact with brain endothelial cells produce gelatinolytic serine proteases, the amount of which increased in the presence of the ROCK inhibitor Y27632. Therefore, it is conceivable that the mesenchymal type of cell movement might be superior to the ameboid type during migration of melanoma cells through the brain endothelium.

Using atomic force microscopy, we have measured the melanoma=endothelial adhesion force in the absence and presence of Y27632. This method monitors initial steps of cell-cell interaction, before firm adhesion is established. As described previously (Vegh et al., 2012), the total 
Role of Rho/ROCK in melanoma brain metastasis formation 2

Figure 8. Role of melanoma versus endothelial Rho/ROCK signaling in the transendothelial migration of melanoma cells. RBEC(CT04), A2058(CT04), and B16/ F10(CT04) represent cells pretreated with $1 \mu \mathrm{g} / \mathrm{ml} \mathrm{CT04}$ for $150 \mathrm{~min}$. Transendothelial migration was performed for $5 \mathrm{~h}$. Results are expressed as. \% control (no CT04 pretreatment) and given as mean $\pm \mathrm{SD}$. $\mathrm{N}=2, *=\mathrm{P}<0.05$ compared with control, as assessed by ANOVA and Bonferroni's post hoc test.
32

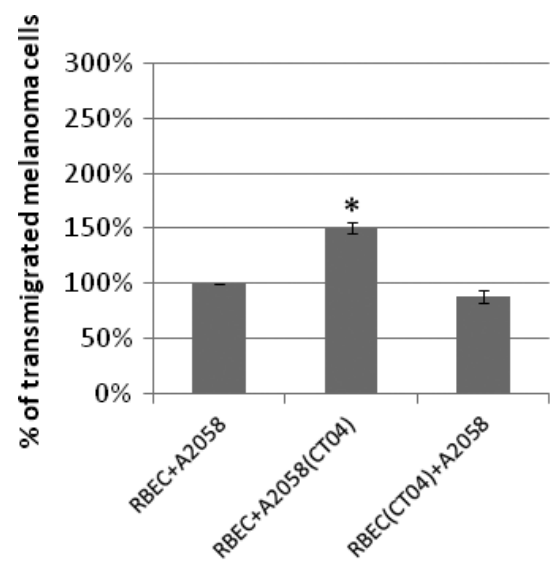

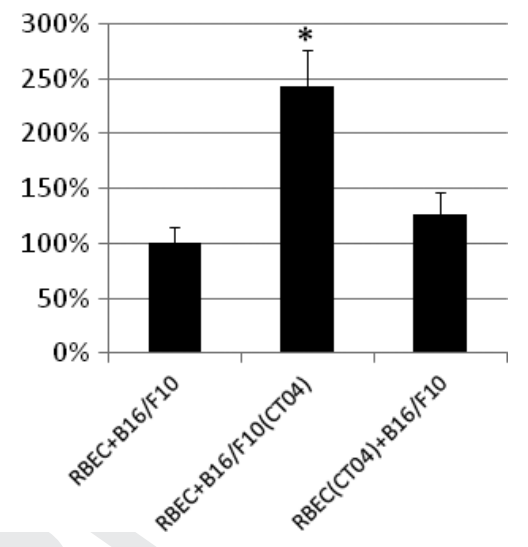

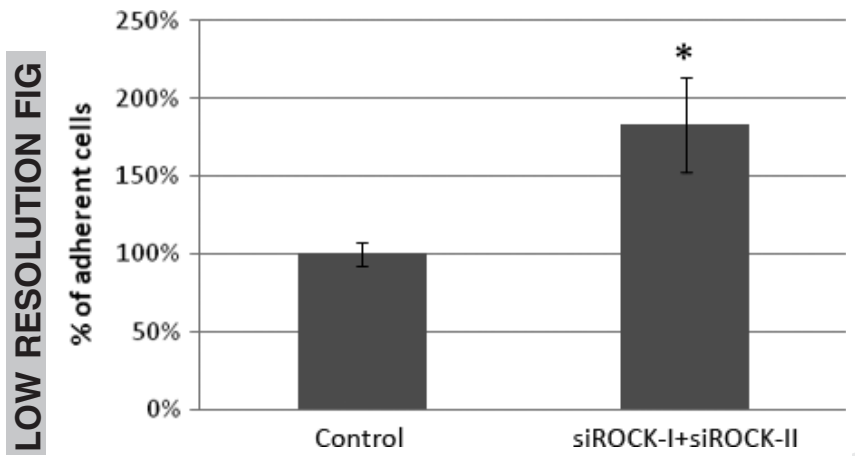

33 Figure 9. Effect of ROCK-I and ROCK-II silencing on the adhesion of melanoma cells onto brain endothelial cells. ROCK-I and ROCK-I genes were silenced in A2058 melanoma cells with an efficiency of 49 and $63 \%$, respectively, as assessed by real-time PCR. Melanoma cells were fluorescently labeled and plated onto confluent D3 monolayers for $90 \mathrm{~min}$. After washing of non-adherent cells, attached melanoma cells were counted. Control = cells transfected with a non-targeting RNA duplex. Results are expressed as $\%$ control and given as mean $\pm \mathrm{SD} . \mathrm{N}=3, *=\mathrm{P}<0.05$ as assessed by Student's t-test.

adhesion force is composed of elementary forces of roughly $20 \mathrm{pN}$ size. Present as stairlike jumps on the retraction (retrace) phase of the force curve, they correspond to individual rupture events between the two cells (insert on Figure S3B). The total adhesion force can be characterized with the size and the number of elementary jumps. It seems that mainly the elevation of the number of the ruptures is responsible for the ROCK inhibitorinduced increase in the total adhesion force; the size of the ruptures grows only on shorter time scales.

Theoretically, the increased adhesiveness can be due to the increased expression of adhesion molecules in endothelial and/or melanoma cells, to the increased affinity and/or velocity of the adhesion molecule(s), or to the increase in the number of adhesion molecules coming in contact with their target (i.e. increase in the contact surface between the two cell types). Cell flattening might result in an increase in the area of the intercellular contact, making more surface molecules accessible. Therefore, the ROCK inhibitor-induced morphological changes themselves are partly responsible for the increase in the adhesion force between melanoma and endothelial cells.

The stronger adhesion properties associated with the mesenchymal invasion were previously suggested to depend on integrins. One hour treatment of scirrhous gastric carcinoma cells with Y27632 upregulated the $\alpha_{3}$ integrin mRNA expression (Matsuoka et al., 2011). We assessed the expression of several integrin subunits which might play role in the adhesion of melanoma cells to endothelial cells: $\alpha_{M} \beta_{2}$ and $\alpha_{L} \beta_{2}$ are ICAM receptors, $\alpha_{4} \beta_{1}$ is a VCAM-1 receptor, and $\alpha_{v} \beta_{3}$ is a PECAM-1 receptor (Humphries et al., 2006). We have shown that ROCK inhibition did not influence the expression of ICAM1, ICAM-2, VCAM-1, and PECAM-1 in cerebral endothelial cells. Similarly, expression of none of the integrin subunits tested was influenced by inhibition of ROCKs in melanoma cells. This suggests that the ROCK-induced increased melanoma-endothelial adhesion is not associated with changes in the expression of melanoma integrins or endothelial CAMs.

We have observed, however, that the Y27632-dependent mechanism enhancing adhesion of melanoma cells to the brain endothelium could be blocked when endothelial cells were pretreated with heparin. Heparin has several biological effects besides its anticoagulant activity. It was shown to bind to cell adhesion molecules (P- and L-selectin, VLA-4 integrin) and to attenuate metastasis formation (Bendas and Borsig, 2012). As the Y27632-induced adhesion of melanoma cells was not attenuated when melanoma cells were pretreated with heparin, we conclude that the activation of integrins on melanoma cells is not responsible for the increased adhesiveness. The phenomenon might rather depend on endothelial selectins and their ligands on melanoma cells. Endothelial P-selectin was found to be crucial in promoting metastasis formation in melanoma (Coupland et al., 2012; Desch et al., 2012; Ludwig et al., 2004). However, sialyl Lewis X-dependent lung colonization of B16 
melanoma cells was found to be dependent on a selectinlike endothelial receptor distinct from E- or P-selectin (Zhang et al., 2002).

Our data revealed that increased adhesion of melanoma cells was accompanied by an elevated rate of transmigration and a significant increase in the number of brain metastasis formation in vivo. Using B16/F10 murine melanoma cells, we could observe a relatively low number of parenchymal brain metastases, which is consistent with literature data (Zhang et al., 2009). Leptomeningeal and ventricular metastases were more frequent. However - as we wanted to evaluate metastatic cells migrated through the BBB - these were not counted; only metastases of at least $500 \mu \mathrm{m}$ distances from the meninges and ventricles were considered. In mice treated with Y27632, the number of parenchymal metastases was still low, but significantly higher than in control conditions, which confirms our in vitro results.

According to our results, migration of melanoma cells through the BBB seems to depend on tumor but not on endothelial Rho/ROCK signaling. Brain endothelial tight junction proteins - which were shown to be involved in the transmigration of melanoma cells (Fazakas et al., 2011) - are linked to the actin cytoskeleton and are influenced by ROCKs. Inhibition of Rho/ROCK signaling has been shown to prevent $\mathrm{Ca}^{2+}$-induced junctional disassembly in both epithelial and brain endothelial cells (Samarin et al., 2007; Wilhelm et al., 2007). ROCK enhances BBB permeability via disruption of tight junction proteins in subarachnoid hemorrhage (Fujii et al., 2012), while inhibition of ROCK was found to attenuate the HIV1 Tat protein-induced decrease in occludin levels in brain endothelial cells (Xu et al., 2012). Altogether these data indicate that inhibition of the Rho/ROCK pathway prevents the disruption of the tight junctions in different pathological conditions. Moreover, the ROCK inhibitor Y27632 increases the transendothelial electrical resistance of cerebral endothelial cells (unpublished results). Therefore, it is not surprising that increase in the transendothelial migration of melanoma cells is not due to the inhibition of the Rho/ROCK pathway in endothelial cells. However, Li et al. (Li et al., 2006) have observed that inhibition of endothelial ROCK with Y27632 or overexpression of a ROCK dominant-negative mutant in endothelial cells prevents $\mathrm{NCl}-\mathrm{H} 209$ small cell lung cancer cells to migrate through a brain endothelial monolayer. These data suggest that different tumor cell types may activate different mechanisms during transendothelial migration.

In conclusion, our data demonstrate that inhibition of the Rho/ROCK pathway in melanoma cells enhances transmigration of melanoma cells through the BBB. We have identified the increased attachment of melanoma cells to the brain endothelium as an underlying mechanism. It may be hypothesized that this might depend on the flattening of melanoma cells (on the morphological level) and possibly on selectins (on the molecular level).
Our data suggest that the mesenchymal type of cell movement (induced by ROCK inhibition) is more important than the ameboid type during migration of melanoma cells through the brain endothelium. This appears to have clinical consequences, as pharmacological inhibitors of ROCK signaling (e.g., fasudil) are emerging as potent therapeutic agents in cerebral vasospasm and preclinical studies are pursued for their utilization in the treatment of cancer (reviewed in: (Street and Bryan, 2011)).

\section{Methods}

\section{Cell culture and treatments}

Interaction of melanoma cells with the brain endothelium was studied using two human cell lines: the microvascular cerebral endothelial cell line hCMEC/D3 and the A2058 melanoma cell line. The murine melanoma cell line B16/F10 was used to confirm the data obtained with human cells and in the in vivo experiments. For transmigration experiments, primary rat brain endothelial cells (RBECs) were used because of their superior barrier characteristics. A detailed description of the in vitro model is presented in Fazakas et al. (2011) and Wilhelm et al. (2011). A2058, B16/F10, and hCMEC/ D3 (abbreviated D3) were maintained as described previously (Fazakas et al., 2011). RBECs were isolated from 2-week-old rats, as described previously (Hutamekalin et al., 2008; Wilhelm et al., 2007). Briefly, after removal of meninges, cerebral cortices were cut into small pieces and digested in two steps with collagenase and collagenase/dispase followed by centrifugation on percoll gradient. Isolated microvessels were plated on fibronectin/collagen-coated dishes. Endothelial cells growing out of the microvessels were cultured in DMEM/F12 (Life Technologies), 10\% plasma-derived 3 serum (PDS, First Link), and growth factors. In the first 2 days, $4 \mu \mathrm{g} /$ $\mathrm{ml}$ puromycin was added to remove contaminating cells.

Y27632 (Tocris) and fasudil (Santa Cruz) (ROCK-I and ROCK-II 4 inhibitors) were used in a concentration of $10 \mu \mathrm{M}$. Heparin (Sigma) was $\mathbf{5}$ applied in a concentration of $5 \mathrm{mg} / \mathrm{ml}$ for $90 \mathrm{~min}$. The Rac inhibitor EHT1864 (Tocris) was used in a concentration of $50 \mu \mathrm{M}$. Selective 6 inhibition of Rho in either RBEC or melanoma cells was performed using CT04 (cell permeable C3 transferase exoenzyme from Clostridium botulinum inactivating the GTPases RhoA, RhoB, and RhoC; Cytoskeleton Inc.2) in a concentration of $1 \mu \mathrm{g} / \mathrm{ml}$ for $150 \mathrm{~min}$.

\section{Attachment of melanoma cells to brain endothelial cells}

Brain endothelial cells were grown until confluency in 24-well plates. Melanoma cells were fluorescently labeled using Oregon Green ${ }^{\circledR} 488$ carboxylic acid diacetate succinimidyl ester (abbreviated OG; Life Technologies) using the protocol supplied by the manufacturer. A total of $5 \times 10^{4}$ melanoma cells/well were loaded onto the endothelial monolayer in serum-free medium and left for $90 \mathrm{~min}$. After washing, cells were fixed using ethanol/acetic acid (95/5) at $-20^{\circ} \mathrm{C}$ for $5 \mathrm{~min}$. Melanoma cells attached to endothelial cells were photographed and counted using the IMAGE-PRO PLUS software (Media Cybernetics).

\section{Phalloidin staining of the actin cytoskeleton}

Cells were fixed with $4 \%$ formaldehyde and permeabilized using acetone at $-20^{\circ} \mathrm{C}$ for $10 \mathrm{~min}$. After blocking, cells were stained with Alexa488-phalloidin (Life Technologies). Mounting was performed in antifading embedding medium (Biomeda), and the distribution of the $\mathbf{9}$ signal was studied using a Nikon Eclipse TE2000U photomicroscope with epifluorescent capabilities connected to a digital camera (Spot RT KE). 


\section{Detection of gelatinolytic serine proteases}

D3 cells were grown in 12-well plates. A total of $2 \times 10^{5}$ A2058 melanoma cells were plated onto the endothelial monolayer in serum-free medium and left for $5 \mathrm{~h}$. Culture media were collected, clarified by centrifugation at $10000 \times g$ for $10 \mathrm{~min}$ on $4^{\circ} \mathrm{C}$, and prepared in mercaptoethanol-free Laemmli buffer. Samples were electrophoresed under non-denaturing conditions in a polyacrylamide gel containing $1.5 \mathrm{mg} / \mathrm{ml}$ gelatin. Gels were washed two times in $2.5 \%$ Triton X-100 and two times in water and incubated for 2 days at $37^{\circ} \mathrm{C}$ in a buffer containing $50 \mathrm{mM}$ Tris $\mathrm{pH}=7.4,0.2 \mathrm{M} \mathrm{NaCl}$, and 5 mM EDTA. Gels were stained with Coomassie BBR-250 for 20 min and destained using 10\% methanol and 10\% acetic acid until the gelatinolytic bands became visible.

\section{Measurement of adhesion forces between melanoma and endothelial cells using atomic force microscopy (AFM)}

\section{Instrumentation}

Experiments were performed with an Asylum MFP-3D-type atomic

10 force microscope (Asylum Research), having an Axiovert 200 microscope as a support, and the MFP-3D Xop driver program,

11 written in Igor Pro software (v. 6.22A; Wavemetrics). Silicon nitride

12 tipless cantilevers were used (MikroMasch). Their spring constant was defined by thermal calibration method (Hutter and Benchhoefer, 1993), giving an average of $30 \mathrm{pN} / \mathrm{nm}$. Cantilevers were functionalized with a multilayer build-up, as follows: overnight incubation with biotinylated-BSA, 15 min with streptavidin, 1-2 min with biotinylated Concanavalin-A (Vegh et al., 2012; Zhang et al., 2006).

\section{Experimental setup}

Of $10^{3}$ OG-labeled A2058 cells were placed into a $10 \mathrm{~cm}^{2}$ culture dish containing an approximately $2 \mathrm{~cm}^{2}$ area of confluent D3 culture in the middle of the dish. Force measurements (see below) were performed in Leibovitz L-15 medium (Sigma). After 25 min, the medium was replaced with fresh Leibovitz L-15 medium or one containing $10 \mu \mathrm{M}$ Y27632 ( $T=0)$. Force measurements were continued for 90 min from this time point.

\section{Force measurements}

Immediately after addition of melanoma cells into the endothelial cellcontaining culture dish, before the attachment of the tumor cells to the endothelium or the surface of the dish, a single melanoma cell was brought into contact with the very end of the cantilever to achieve the attachment between them. The position of the melanoma cell on the cantilever has been monitored continuously during the experiment, and no considerable change occurred. The melanoma cell-containing cantilever was brought in contact with the endothelial monolayer (Figure S3A) with a frequency of $0.033 \mathrm{~Hz}$. The travel speed of the 'cell probe' was set to $2 \mu \mathrm{m} / \mathrm{s}$ both for lowering (trace) and for pulling back (retrace). The total loading force applied was $2 \mathrm{nN}$. The intercellular adhesion forces were determined from the retrace curves by calculating the relative level difference between the maximal downward deflection of the cantilever and its alignment after total unbinding (Figure S3B). As described previously (Vegh et al., 2012), the total adhesion force consists of elementary forces, which present as stairlike jumps on the retraction (retrace) phase of the force curve

13 (Figure S3B). A homemade MATLAB (MathWorks, routine was developed to extract total adhesion force values, and statistics to quantify the number and average size of stairlike jumps. Individual jumps on retract curves were identified as the level difference between two adjacent points passing a threshold. Twofold of the standard deviation taken from the last 50 points of each curve was given as threshold.

\section{Real-time PCR}

Total RNA was isolated from untreated A2058 cells or cells treated with Y27632 for 90 min using TRIzol reagent (Life Technologies) following the manufacturer's recommendations. RNA was transcribed into cDNA using the SuperScript III reverse transcription kit (Life Technologies). The amplification was performed on a BioRad iQ5 instrument using Maxima SYBR Green Mix (Fermentas) under 14 the following conditions: 40 cycles of $95^{\circ} \mathrm{C}$ for $15 \mathrm{~s}, 56^{\circ} \mathrm{C}$ for $30 \mathrm{~s}$, $72^{\circ} \mathrm{C}$ for $30 \mathrm{~s}$. The primer pairs used for amplification are summarized in Supplementary Table 1. Determination of threshold cycles and quantitation was performed using the software of the instrument.

\section{Western blot analysis}

Cells were harvested in ice-cold RIPA buffer. Protein concentration was measured using the BCA assay (Pierce). Proteins were electro- 15 phoresed and blotted onto PVDF (Millipore) membranes. After 16 blocking, anti-N-cadherin (Transduction Laboratories) and anti- $\beta$-actin 17 (Sigma) primary antibodies were used. Secondary antibodies were from Amersham. The immunoreaction was visualized using the Immobilon Western Chemiluminescent HRP Substrate (Millipore) on X-ray film (Agfa).

Immunofluorescence staining of adhesion molecules D3 cells were cultured until confluency in 96-well plates. Cells were treated with $1 \mu \mathrm{g} / \mathrm{ml}$ LPS or $10 \mathrm{ng} / \mathrm{ml} \mathrm{TNF}-\alpha$ for $6 \mathrm{~h}$. A total of $10^{4}$ A2058 cells or A2058-conditioned media were applied for $90 \mathrm{~min}$. Cells were fixed with methanol/acetone at $-20^{\circ} \mathrm{C}$ for $5 \mathrm{~min}$, then rehydrated in Tris-buffered saline containing 1\% BSA (TBS-BSA) and stained with anti-adhesion molecule (ICAM-1, ICAM-2, VCAM-1, ESelectin, PECAM-1, and CD99) antibodies (Bender Med Systems) 19 followed by rabbit anti-goat Alexa568 (in case of CD99) or goat antimouse Alexa568 (all the other adhesion molecules) secondary antibodies. Alexa-labeled secondary antibodies were purchased from Life Technologies. Images were recorded by Olympus IX-81 fluorescence microscope equipped with XM-10 camera.

\section{Transmigration of melanoma cells through brain endothelial monolayers}

Transmigration experiments were performed as described previously (Fazakas et al., 2011; Wilhelm et al., 2011). Briefly, primary RBECs were passed onto fibronectin/collagen-coated $8 \mu \mathrm{m}$ pore size filter inserts (Millipore). After reaching confluency, endothelial cells were supplemented with $550 \mathrm{nM}$ hydrocortisone, $250 \mu \mathrm{M}$ CPT-CAMP (Sigma), and 17.5 $\mu \mathrm{M}$ Ro 20-1724 (Sigma) from the apical side and astrocyte-conditioned medium from the basolateral side for $24 \mathrm{~h}$. Then, $10^{5}$ OG-labeled melanoma cells were plated onto the endothelial monolayer in serum-free medium. The lower compartment was loaded with serum-free medium containing $100 \mu \mathrm{g} / \mathrm{ml}$ type I collagen. Cells were left for $5 \mathrm{~h}$, followed by fixation with ethanol/acetic acid. Cells from the upper compartment were removed with a cotton swab, and melanoma cells migrated through the endothelial monolayer and the pores of the filter were counted.

\section{Evaluation of brain metastasis formation in vivo}

Seven- to-10-week-old C57BL/6 male mice were anesthetized with Avertin (Fluka) administered intraperitoneally $(30 \mathrm{mg} / 100 \mathrm{~g}$ body weight in a volume of $0.35 \mathrm{ml}$ ). A total of $10^{6}$ B16/F10 melanoma cells were injected in $200 \mu \mathrm{l}$ Ringer-HEPES solution into the right common carotid artery using a syringe with a 30-gauge needle. Following inoculation of tumor cells, $500 \mu \mathrm{g} / \mathrm{kg}$ Y 27632 was administered intravenously to some animals. After 10 days, animals were sacrificed (terminal anesthesia with Avertin), transcardially perfused with phosphate-buffered saline (PBS, $10 \mathrm{mM}, \mathrm{pH}=7.4$ ), followed by 
3.5\% paraformaldehyde (Sigma) in PBS. Brains were removed and placed into the same fixative overnight at $4^{\circ} \mathrm{C}$. After post-fixation, brains were cryoprotected in 30\% sucrose (in $10 \mathrm{mM}$ PBS) for at least 2 days at $4^{\circ} \mathrm{C}$. Fifty micrometer cryosections were prepared, and melanotic lesions were counted. Only parenchymal metastases (at a distance of at least $500 \mu \mathrm{m}$ from the meninges and ventricles) were considered. All mice were housed and treated in accordance with widely accepted standards, and the protocols were approved by the institutional care and the regional committee for animal research.

\section{Cneoifie lenodedown of ROCK-I and ROCK-II by RNA} PPROVED

ex oligoribonucleotides were designed using OCK-iT ${ }^{T M} R N A i$ designer and were purchased ies. The sequences used are summarized in Supplementary Table 2. A2058 cells were plated at 50\% confluency. Transfection of oligonucleotides was performed in Opti-MEM medium (Life Technologies) containing $20 \mathrm{nM}$ RNA and Dharma-

21 FECT 4 transfection reagent (Thermo Scientific) following the manufacturer's instructions. After $8 \mathrm{~h}$, the medium was changed to regular culture medium. To increase the efficiency, a second transfection was performed the following day. Cells were used $24 \mathrm{~h}$ after the second transfection. At the same time, transfection efficiency was analyzed by real-time PCR.

\section{Acknowledgements}

This work was supported by grants from the Hungarian Research Fund (OTKA PD-100958, K-100807, K-100684 and K-81180), the National Development Agency (Hungary-Romania Cross-Border Cooperation Programme 2007-2013: HURO/1101/173/2.2.1; and the TÁMOP-4.2.2.A-11/1/KONV-2012-0052 project). I. Wilhelm and L. Cervenak are supported by the János Bolyai Research Fellowship of the Hungarian Academy of Sciences (BO/00320/12/8 and BO/00218/ $10 / 8$, respectively). This research was realized in the frames of TÁMOP 4.2.4. A/2-11-1-2012-0001 'National Excellence Program Elaborating and operating an inland student and researcher personal support system convergence program', the project was subsidized by the European Union and co-financed by the European Social Fund (C. Fazakas, A.G. Végh). H. Bauer and H.C. Bauer are participants of the NEUROBID consortium (EU 7th FP). G.J. Guillemin is supported by the Cure for Life Foundation (Australia).

\section{References}

Abbott, N.J., Patabendige, A.A., Dolman, D.E., Yusof, S.R., and Begley, D.J. (2010). Structure and function of the blood-brain barrier. Neurobiol. Dis. 37, 13-25.

Adachi, S., Yasuda, I., Nakashima, M., Yamauchi, T., Yoshioka, T., Okano, Y., Moriwaki, H., and Kozawa, O. (2011). Rho-kinase inhibitor upregulates migration by altering focal adhesion formation via the Akt pathway in colon cancer cells. Eur. J. Pharmacol. 650, 145-150.

Bendas, G., and Borsig, L. (2012). Cancer cell adhesion and metastasis: selectins, integrins, and the inhibitory potential of heparins. Int. J. Cell. Biol. 2012, 676731.

Chen, G., and Davies, M.A. (2012). Emerging insights into the molecular biology of brain metastases. Biochem. Pharmacol. 83, 305-314.

Chen, Y., Wang, D., Guo, Z. et al. (2011). Rho kinase phosphorylation promotes ezrin-mediated metastasis in hepatocellular carcinoma. Cancer Res. 71, 1721-1729.

Coupland, L.A., Chong, B.H., and Parish, C.R. (2012). Platelets and P-selectin control tumor cell metastasis in an organ-specific manner and independently of NK cells. Cancer Res. 72, 46624671.

Desch, A., Strozyk, E.A., Bauer, A.T., Huck, V., Niemeyer, V., Wieland, T., and Schneider, S.W. (2012). Highly invasive melanoma cells activate the vascular endothelium via an MMP-2/integrin alphavbeta5-induced secretion of VEGF-A. Am. J. Pathol. 181, 693-705.

Fazakas, C., Wilhelm, I., Nagyoszi, P. et al. (2011). Transmigration of melanoma cells through the blood-brain barrier: role of endothelial tight junctions and melanoma-released serine proteases. PLoS ONE 6, e20758.

Fujii, M., Duris, K., Altay, O., Soejima, Y., Sherchan, P., and Zhang, J.H. (2012). Inhibition of Rho kinase by hydroxyfasudil attenuates brain edema after subarachnoid hemorrhage in rats. Neurochem. Int. 60, 327-333.

Fujita, M., Otsuka, Y., Yamada, S., Iwakawa, M., and Imai, T. (2011). $X$-ray irradiation and Rho-kinase inhibitor additively induce invasiveness of the cells of the pancreatic cancer line, MIAPaCa-2, which exhibits mesenchymal and amoeboid motility. Cancer Sci. 102, 792-798.

Guezguez, B., Vigneron, P., Lamerant, N., Kieda, C., Jaffredo, T., and Dunon, D. (2007). Dual role of melanoma cell adhosion molecule (MCAM)/CD146 in lymphocyto ondothelium interaction: MCAMH CD146 promotes rolling via microvilli induction in lymphocyte and is an endothelial adhesion receptor. J. Immunol. 179, 6673-6685.

Humphries, J.D., Byron, A., and Humphries, M.J. (2006). Integrin ligands at a glance. J. Cell Sci. 119, 3901-3903.

Hutamekalin, P., Farkas, A.E., Orbok, A. et al. (2008). Effect of nicotine and polyaromtic hydrocarbons on cerebral endothelial cells. Cell Biol. Int. 32, 198-209.

Hutter, J.L., and Benchhoefer, J. (1993). Calibration of atomic-force microscope tips. Rev. Sci. Instrum. 64, 1868-1873.

Itoh, K., Yoshioka, K., Akedo, H., Uehata, M., Ishizaki, T., and Narumiya, S. (1999). An essential part for Rho-associated kinase in the transcellular invasion of tumor cells. Nat. Med. 5, 221-225.

Kidera, Y., Tsubaki, M., Yamazoe, Y. et al. (2010). Reduction of lung metastasis, cell invasion, and adhesion in mouse melanoma by statin-induced blockade of the Rho/Rho-associated coiled-coil-containing protein kinase pathway. J. Exp. Clin. Cancer Res. 29, 127.

Kozlova, N.1., Morozovich, G.E., Chubukina, A.N., Shtil, A.A., and Berman, A.E. (2004). Expression of integrins, anchorage dependent apoptosis and invasivenoss of multidrug rosistant human breast carcinoma cells. EXCLI J. 3, 58-67.

Li, B., Zhao, W.D., Tan, Z.M., Fang, W.G., Zhu, L., and Chen, Y.H. (2006). Involvement of Rho/ROCK signalling in small cell lung cancer migration through human brain microvascular endothelial cells. FEBS Lett. 580, 4252-4260.

Ludwig, R.J., Boehme, B., Podda, M., Henschler, R., Jager, E., Tandi, C., Boehncke, W.H., Zollner, T.M., Kaufmann, R., and Gille, J. (2004). Endothelial P-selectin as a target of heparin action in experimental melanoma lung metastasis. Cancer Res. 64, 27432750.

Matsuoka, T., Yashiro, M., Kato, Y., Shinto, O., Kashiwagi, S., and Hirakawa, K. (2011). RhoA/ROCK signaling mediates plasticity of scirrhous gastric carcinoma motility. Clin. Exp. Metastasis 28, 627636 .

Motlapally, R., Jobling, A.I., Gontle, A., and McBrion, N.A. (2006). Characterization of the integrin receptor subunit profile in the mammalian sclera. Mol. Vis. 12, 725-734.

Perides, G., Zhuge, Y., Lin, T., Stins, M.F., Bronson, R.T., and Wu, J.K. (2006). The fibrinolytic system facilitates tumor cell migration across the blood-brain barrier in experimental melanoma brain metastasis. BMC Cancer 6, 56.

Routhier, A., Astuccio, M., Lahey, D. et al. (2010). Pharmacological inhibition of Rho-kinase signaling with Y-27632 blocks melanoma tumor growth. Oncol. Rep. 23, 861-867. 
Sahai, E., and Marshall, C.J. (2003). Differing modes of tumour cell invasion have distinct requirements for Rho/ROCK signalling and extracellular proteolysis. Nat. Cell Biol. 5, 711-719.

Samarin, S.N., Ivanov, A.I., Flatau, G., Parkos, C.A., and Nusrat, A. (2007). Rho/Rho-associated kinase-II signaling mediates disassembly of epithelial apical junctions. Mol. Biol. Cell 18, 3429-3439.

Sanz-Moreno, V., Gadea, G., Ahn, J., Paterson, H., Marra, P., Pinner, S., Sahai, E., and Marshall, C.J. (2008). Rac activation and inactivation control plasticity of tumor cell movement. Cell 135, 510-523.

Spencer, C., Montalvo, J., McLaughlin, S.R., and Bryan, B.A. (2011). Small molecule inhibition of cytoskeletal dynamics in melanoma tumors results in altered transcriptional expression patterns of key genes involved in tumor initiation and progression. Cancer Genomics Proteomics 8, 77-85.

Street, C.A., and Bryan, B.A. (2011). Rho kinase proteins-pleiotropic modulators of cell survival and apoptosis. Anticancer Res. 31, 3645-3657.

Symons, M., and Segall, J.E. (2009). Rac and Rho driving tumor invasion: who's at the wheel?. Genome Biol. 10, 213.

Vegh, A.G., Fazakas, C., Nagy, K., Wilhelm, I., Molnar, J., Krizbai, I.A., Szegletes, Z., and Varo, G. (2012). Adhesion and stress relaxation forces between melanoma and cerebral endothelial cells. Eur. Biophys. J. 41, 139-145.

Vishnubhotla, R., Bharadwaj, S., Sun, S., Metlushko, V., and Glover, S.C. (2012). Treatment with Y-27632, a ROCK Inhibitor, Increases the Proinvasive Nature of SW620 Cells on 3D Collagen Type 1 Matrix. Int. J. Cell. Biol. 2012, 259142.

Wilhelm, I., Farkas, A.E., Nagyoszi, P., Varo, G., Balint, Z., Vegh, G.A., Couraud, P.O., Romero, I.A., Weksler, B., and Krizbai, I.A. (2007). Regulation of cerebral endothelial cell morphology by extracellular calcium. Phys. Med. Biol. 52, 6261-6274.

Wilhelm, I., Fazakas, C., and Krizbai, I.A. (2011). In vitro models of the blood-brain barrier. Acta Neurobiol. Exp. (Wars) 71, 113-128.

Wilhelm, I., Molnar, J., Fazakas, C., Hasko, J., and Krizbai, I.A. (2013). Role of the Blood-Brain Barrier in the Formation of Brain Metastases. Int. J. Mol. Sci. 14, 1383-1411.

Wolf, K., Mazo, I., Leung, H., Engelke, K., von Andrian, U.H., Deryugina, E.I., Strongin, A.Y., Brocker, E.B., and Friedl, P. (2003). Compensation mechanism in tumor cell migration: mesenchymal-amoeboid transition after blocking of pericellular proteolysis. J. Cell Biol. 160, 267-277.

Wyckoff, J.B., Pinner, S.E., Gschmeissner, S., Condeelis, J.S., and Sahai, E. (2006). ROCK- and myosin-dependent matrix deformation enables protease-independent tumor-cell invasion in vivo. Curr. Biol. 16, 1515-1523

Xu, R., Feng, X., Xie, X., Zhang, J., Wu, D., and Xu, L. (2012). HIV-1 Tat protein increases the permeability of brain endothelial cells by both inhibiting occludin expression and cleaving occludin via matrix metalloproteinase-9. Brain Res. 1436, 13-19.

Yang, X., Liu, Y., Zong, Z., and Tian, D. (2010). The Rho kinase inhibitor fasudil inhibits the migratory behaviour of 95-D lung carcinoma cells. Biomed. Pharmacother. 64, 58-62.

Yang, X., Di, J., Zhang, Y., Zhang, S., Lu, J., Liu, J., and Shi, W. (2012). The Rho-kinase inhibitor inhibits proliferation and metastasis of small cell lung cancer. Biomed. Pharmacother. 66, 221-227.

Ying, H., Biroc, S.L., Li, W.W., Alicke, B., Xuan, J.A., Pagila, R., Ohashi, Y., Okada, T., Kamata, Y., and Dinter, H. (2006). The Rho kinase inhibitor fasudil inhibits tumor progression in human and rat tumor models. Mol. Cancer Ther. 5, 2158-2164.

Yui, Y., Itoh, K., Yoshioka, K. et al. (2010). Mesenchymal mode of migration participates in pulmonary metastasis of mouse osteosarcoma LM8. Clin. Exp. Metastasis 27, 619-630.

Zhang, J., Nakayama, J., Ohyama, C., Suzuki, M., Suzuki, A., Fukuda, M., and Fukuda, M.N. (2002). Sialyl Lewis X-dependent lung colonization of B16 melanoma cells through a selectin-like endothelial receptor distinct from E- or P-selectin. Cancer Res. 62, 4194-4198.

Zhang, X., Wojcikiewicz, E.P., and Moy, V.T. (2006). Dynamic adhesion of T lymphocytes to endothelial cells revealed by atomic force microscopy. Exp. Biol. Med. (Maywood) 231, 1306-1312.

Zhang, C., Zhang, F., Tsan, R., and Fidler, I.J. (2009). Transforming growth factor-beta2 is a molecular determinant for site-specific melanoma metastasis in the brain. Cancer Res. 69, 828-835.

Zhu, F., Zhang, Z., Wu, G., Li, Z., Zhang, R., Ren, J., and Nong, L. (2011). Rho kinase inhibitor fasudil suppresses migration and invasion though down-regulating the expression of VEGF in lung cancer cell line A549. Med. Oncol. 28, 565-571.

\section{Supporting information}

Additional Supporting Information may be found in the online version of this article:

Figure S1. Expression of adhesion molecules on A2058 cells.

Figure S2. Expression of adhesion molecules on hCMEC/D3 cells.

Figure S3. Measurement of adhesion forces using atomic force microscopy.

Table S1 Primers used for PCR.

Table S2 Stealth siRNA sequences used for silencing of ROCK-I and ROCK-II. 


\section{Author Query Form}

Journal: $\quad$ PCMR

Article: $\quad 12169$

Dear Author,

During the copy-editing of your paper, the following queries arose. Please respond to these by marking up your proofs with the necessary changes/additions. Please write your answers on the query sheet if there is insufficient space on the page proofs. Please write clearly and follow the conventions shown on the attached corrections sheet. If returning the proof by fax do not write too close to the paper's edge. Please remember that illegible mark-ups may delay publication.

Many thanks for your assistance.

\begin{tabular}{|c|c|c|}
\hline Query reference & Query & Remarks \\
\hline 1 & $\begin{array}{l}\text { WILEY: Please insert the published online date for online accepted publi- } \\
\text { cation. }\end{array}$ & \\
\hline 2 & $\begin{array}{l}\text { AUTHOR: Running title should not exceed a maximum of } 40 \text { characters. } \\
\text { Please check and provide a suitable short title to conform to the journal } \\
\text { style. }\end{array}$ & \\
\hline 3 & $\begin{array}{l}\text { AUTHOR: Please give address information for Life Technologies: town, state } \\
\text { (if applicable), and country. }\end{array}$ & \\
\hline 4 & $\begin{array}{l}\text { AUTHOR: Please give address information for Santa Cruz: town, state (if } \\
\text { applicable), and country. }\end{array}$ & \\
\hline 5 & $\begin{array}{l}\text { AUTHOR: Please give address information for Sigma: town, state (if } \\
\text { applicable), and country. }\end{array}$ & \\
\hline 6 & $\begin{array}{l}\text { AUTHOR: Please give address information for Tocris: town, state (if } \\
\text { applicable), and country. }\end{array}$ & \\
\hline 7 & $\begin{array}{l}\text { AUTHOR: Please give address information for Cytoskeleton Inc: town, state } \\
\text { (if applicable), and country. }\end{array}$ & \\
\hline 8 & $\begin{array}{l}\text { AUTHOR: Please give address information for Media Cybernetics: town, } \\
\text { state (if applicable), and country. }\end{array}$ & \\
\hline 9 & $\begin{array}{l}\text { AUTHOR: Please give address information for Biomeda: town, state (if } \\
\text { applicable), and country. }\end{array}$ & \\
\hline 10 & $\begin{array}{l}\text { AUTHOR: Please give address information for Asylum Research: town, state } \\
\text { (if applicable), and country. }\end{array}$ & \\
\hline 11 & $\begin{array}{l}\text { AUTHOR: Please give address information for Wavemetrics: town, state (if } \\
\text { applicable), and country. }\end{array}$ & \\
\hline 12 & $\begin{array}{l}\text { AUTHOR: Please give address information for MikroMasch: town, state (if } \\
\text { applicable), and country. }\end{array}$ & \\
\hline 13 & $\begin{array}{l}\text { AUTHOR: Please give address information for MathWorks: town, state (if } \\
\text { applicable), and country. }\end{array}$ & \\
\hline 14 & $\begin{array}{l}\text { AUTHOR: Please give address information for Fermentas: town, state (if } \\
\text { applicable), and country. }\end{array}$ & \\
\hline 15 & $\begin{array}{l}\text { AUTHOR: Please give address information for Pierce: town, state (if } \\
\text { applicable), and country. }\end{array}$ & \\
\hline
\end{tabular}




\begin{tabular}{|c|c|}
\hline 16 & $\begin{array}{l}\text { AUTHOR: Please give address information for Millipore: town, state (if } \\
\text { applicable), and country. }\end{array}$ \\
\hline 17 & $\begin{array}{l}\text { AUTHOR: Please give address information for Transduction Laboratories: } \\
\text { town, state (if applicable), and country. }\end{array}$ \\
\hline 18 & $\begin{array}{l}\text { AUTHOR: Please give address information for Agfa: town, state (if applica- } \\
\text { ble), and country. }\end{array}$ \\
\hline 19 & $\begin{array}{l}\text { AUTHOR: Please give address information for Bender Med Systems: town, } \\
\text { state (if applicable), and country. }\end{array}$ \\
\hline 20 & $\begin{array}{l}\text { AUTHOR: Please check and suggest whether the phrase " and were" can be } \\
\text { changed to "which was" for clarity in the sentence "Stealth }{ }^{\text {TM }} \text { siRNA duplex } \\
\text {... Life Technologies." }\end{array}$ \\
\hline 21 & $\begin{array}{l}\text { AUTHOR: Please give address information for Thermo Scientific: town, state } \\
\text { (if applicable), and country. }\end{array}$ \\
\hline 22 & $\begin{array}{l}\text { AUTHOR: Guezguez et al. (2007) has not been cited in the text. Please } \\
\text { indicate where it should be cited; or delete from the Reference List. }\end{array}$ \\
\hline 23 & $\begin{array}{l}\text { AUTHOR: Kozlova et al. (2004) has not been cited in the text. Please indicate } \\
\text { where it should be cited; or delete from the Reference List. }\end{array}$ \\
\hline 24 & $\begin{array}{l}\text { AUTHOR: Metlapally et al. (2006) has not been cited in the text. Please } \\
\text { indicate where it should be cited; or delete from the Reference List. }\end{array}$ \\
\hline 25 & $\begin{array}{l}\text { AUTHOR: Figure } 1 \text { has been saved at a low resolution of } 157 \mathrm{dpi} \text {. Please } \\
\text { resupply at } 600 \mathrm{dpi} \text {. Check required artwork specifications at http:// } \\
\text { authorservices.wiley.com/bauthor/illustration.asp. }\end{array}$ \\
\hline 26 & $\begin{array}{l}\text { AUTHOR: Figure } 2 \text { has been saved at a low resolution of } 168 \mathrm{dpi} \text {. Please } \\
\text { resupply at } 600 \mathrm{dpi} \text {. Check required artwork specifications at http:// } \\
\text { authorservices.wiley.com/bauthor/illustration.asp. }\end{array}$ \\
\hline 27 & $\begin{array}{l}\text { AUTHOR: Figure } 3 \text { has been saved at a low resolution of } 128 \mathrm{dpi} \text {. Please } \\
\text { resupply at } 600 \mathrm{dpi} \text {. Check required artwork specifications at http:// } \\
\text { authorservices.wiley.com/bauthor/illustration.asp. }\end{array}$ \\
\hline 28 & $\begin{array}{l}\text { AUTHOR: Figure } 4 \text { has been saved at a low resolution of } 155 \mathrm{dpi} \text {. Please } \\
\text { resupply at } 600 \mathrm{dpi} \text {. Check required artwork specifications at http:// } \\
\text { authorservices.wiley.com/bauthor/illustration.asp. }\end{array}$ \\
\hline 29 & $\begin{array}{l}\text { AUTHOR: Figure } 5 \text { has been saved at a low resolution of } 183 \mathrm{dpi} \text {. Please } \\
\text { resupply at } 600 \mathrm{dpi} \text {. Check required artwork specifications at http:// } \\
\text { authorservices.wiley.com/bauthor/illustration.asp. }\end{array}$ \\
\hline 30 & $\begin{array}{l}\text { AUTHOR: Figure } 6 \text { has been saved at a low resolution of } 151 \mathrm{dpi} \text {. Please } \\
\text { resupply at } 600 \mathrm{dpi} \text {. Check required artwork specifications at http:// } \\
\text { authorservices.wiley.com/bauthor/illustration.asp. }\end{array}$ \\
\hline 31 & $\begin{array}{l}\text { AUTHOR: Figure } 7 \text { has been saved at a low resolution of } 156 \mathrm{dpi} \text {. Please } \\
\text { resupply at } 600 \mathrm{dpi} \text {. Check required artwork specifications at http:// } \\
\text { authorservices.wiley.com/bauthor/illustration.asp. }\end{array}$ \\
\hline 32 & $\begin{array}{l}\text { AUTHOR: Figure } 8 \text { has been saved at a low resolution of } 158 \mathrm{dpi} \text {. Please } \\
\text { resupply at } 600 \mathrm{dpi} \text {. Check required artwork specifications at http:// } \\
\text { authorservices.wiley.com/bauthor/illustration.asp. }\end{array}$ \\
\hline 33 & $\begin{array}{l}\text { AUTHOR: Figure } 9 \text { has been saved at a low resolution of } 138 \mathrm{dpi} \text {. Please } \\
\text { resupply at } 600 \mathrm{dpi} \text {. Check required artwork specifications at http:// } \\
\text { authorservices.wiley.com/bauthor/illustration.asp. }\end{array}$ \\
\hline
\end{tabular}


Required software to e-Annotate PDFs: Adobe Acrobat Professional or Adobe Reader (version 8.0 or above). (Note that this document uses screenshots from Adobe Reader $\mathrm{X}$ )

The latest version of Acrobat Reader can be downloaded for free at:http://get.adobe.com/reader/

Once you have Acrobat Reader open on your computer, click on the Comment tab at the right of the toolbar:

닙

This will open up a panel down the right side of the document. The majority of tools you will use for annotating your proof will be in the Annotations section, pictured opposite. We've picked out some of these tools below:

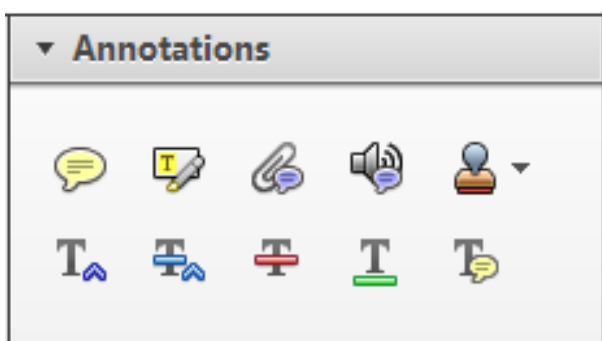

1. Replace (Ins) Tool - for replacing text.

\section{Strikes a line through text and opens up a text} box where replacement text can be entered.

\section{How to use it}

- Highlight a word or sentence.

- Click on the Replace (Ins) icon in the Annotations section.

- Type the replacement text into the blue box that appears.

Idard tramework for the analysis of $\mathrm{m}$ icy Nevertheless, it also led to exog،

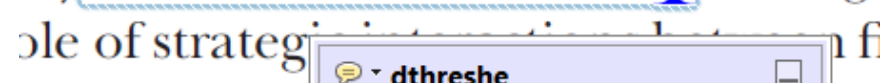
aber of comp 08/06/2011 15:58:17 $\quad$ o

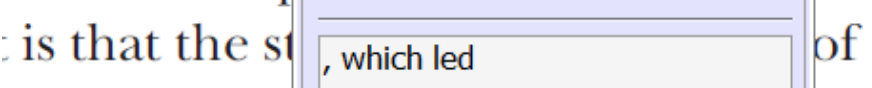
nain compo: be level, are exc nc

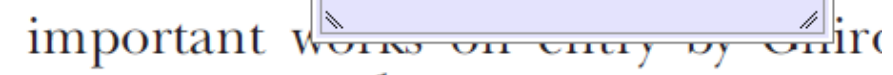
M heneforth) ${ }^{1}$ we anen the 'hlarl $\mathrm{h}$

3. Add note to text Tool - for highlighting a section to be changed to bold or italic.

Th Highlights text in yellow and opens up a text box where comments can be entered.

\section{How to use it}

- Highlight the relevant section of text.

- Click on the Add note to text icon in the Annotations section.

- Type instruction on what should be changed regarding the text into the yellow box that annears.

namic responses of mark ups ent with the VAR evidence

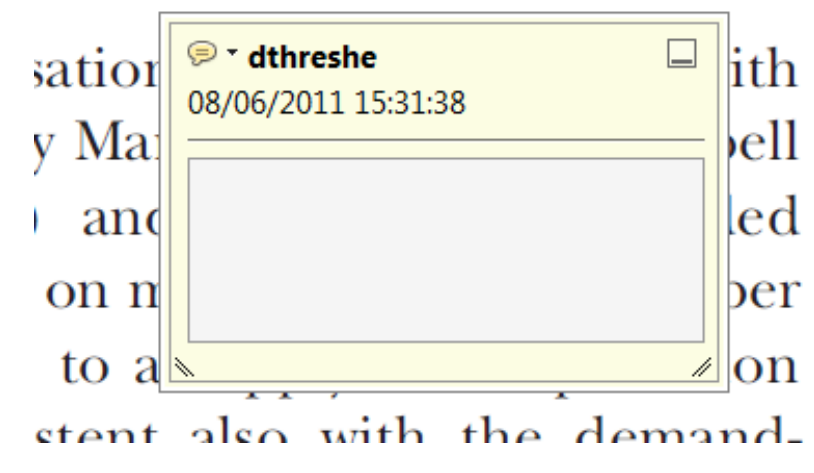

2. Strikethrough (Del) Tool - for deleting text.

Thikes a red line through text that is to be deleted.

\section{How to use it}

- Highlight a word or sentence.

- Click on the Strikethrough (Del) icon in the Annotations section.

there is no room for extra protits al c ups are zero and the number of ret) values are not determined by Blanchard and Kiyetaki (1987), rfect competition in general equilil ts of aggregate demand and supply lassical framework assuming monol eon an evorenois number of firms

\section{Add sticky note Tool - for making notes at} specific points in the text.

\section{Marks a point in the proof where a comment} needs to be highlighted.

\section{How to use it}

- Click on the Add sticky note icon in the Annotations section.

- Click at the point in the proof where the comment should be inserted.

- Type the comment into the yellow box that appears.

lallu allu suppiy silucks. Iviusl ul

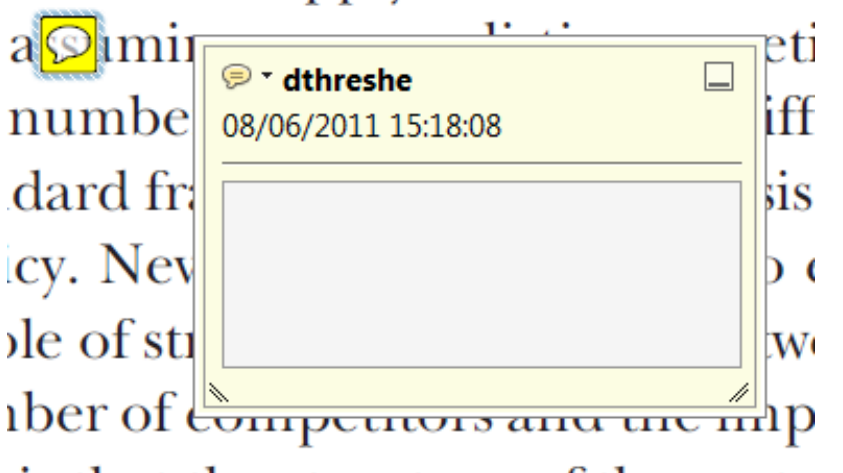

is that the structure of the secto 
5. Attach File Tool - for inserting large amounts of text or replacement figures.

Inserts an icon linking to the attached file in the appropriate pace in the text.

How to use it

- Click on the Attach File icon in the Annotations section.

- Click on the proof to where you'd like the attached file to be linked.

- Select the file to be attached from your computer or network.

- Select the colour and type of icon that will appear in the proof. Click OK.

E N D

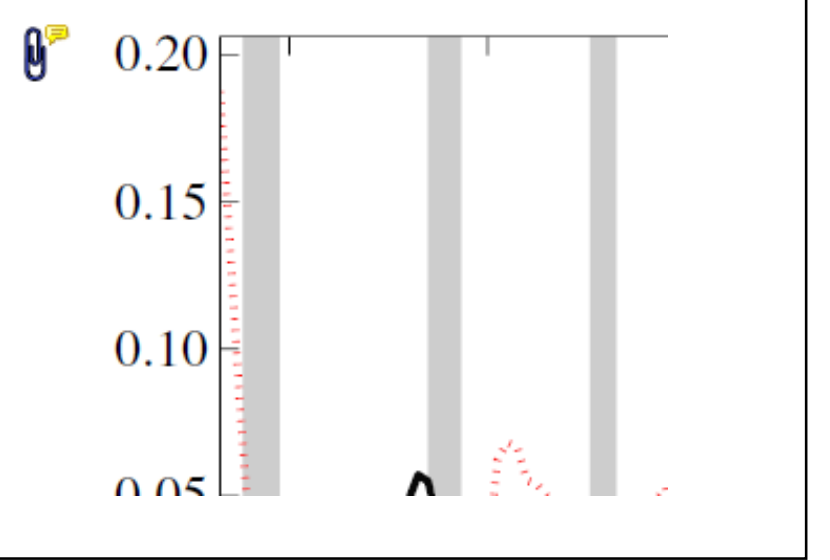

6. Add stamp Tool - for approving a proof if no corrections are required.

- Inserts a selected stamp onto an appropriate place in the proof

\section{How to use it}

- $\quad$ Click on the Add stamp icon in the Annotations section.

- Select the stamp you want to use. (The Approved stamp is usually available directly in the menu that appears).

- Click on the proof where you'd like the stamp to appear. (Where a proof is to be approved as it is, this would normally be on the first page).

of the Dusiness cycie, starting with the on perfect competition, constant ret

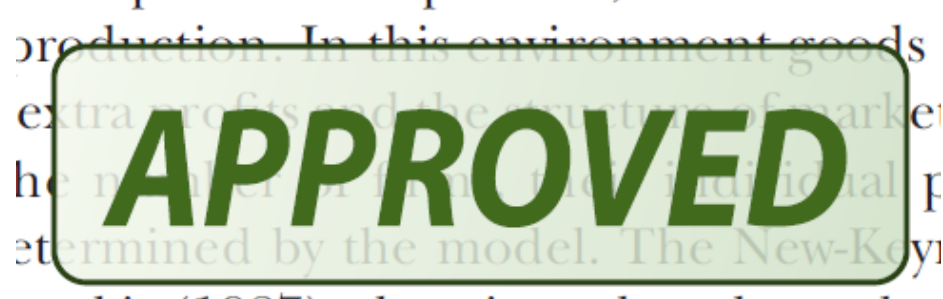

otaki (1987), has introduced produc general equilibrium models with nomin
- Drawing Markups

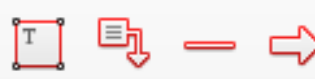

$0 \square \sqrt{6} D$

\section{How to use it}

- Click on one of the shapes in the Drawing Markups section.

- Click on the proof at the relevant point and draw the selected shape with the cursor.

- To add a comment to the drawn shape, move the cursor over the shape until an arrowhead appears.

- Double click on the shape and type any text in the red box that appears.
7. Drawing Markups Tools - for drawing shapes, lines and freeform annotations on proofs and commenting on these marks.

Allows shapes, lines and freeform annotations to be drawn on proofs and for comment to be made on these marks..

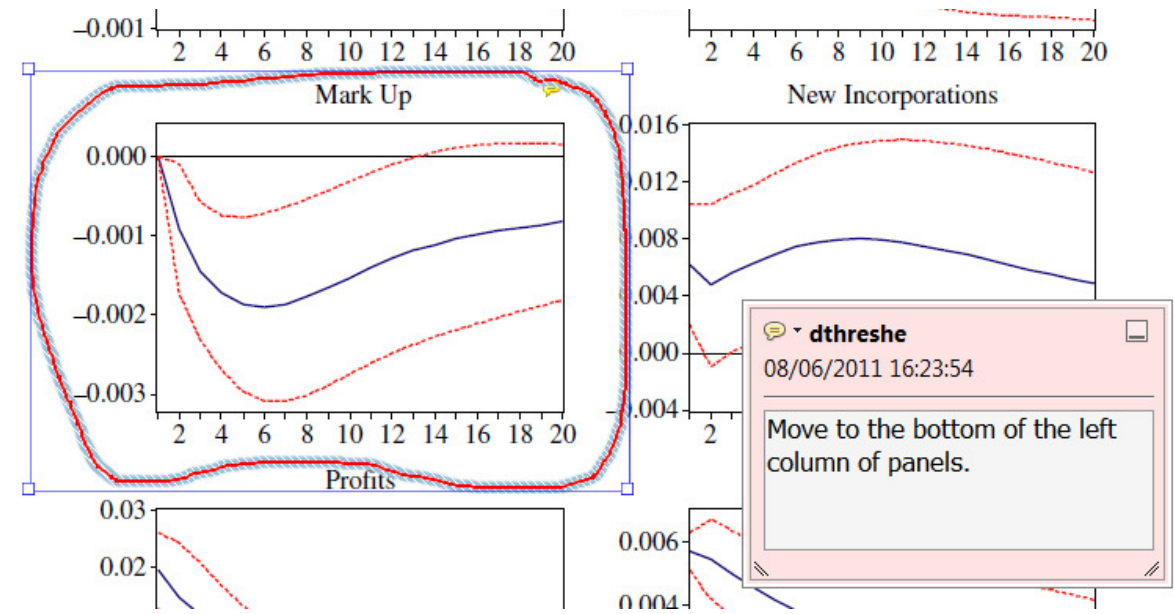

For further information on how to annotate proofs, click on the Help menu to reveal a list of further options:

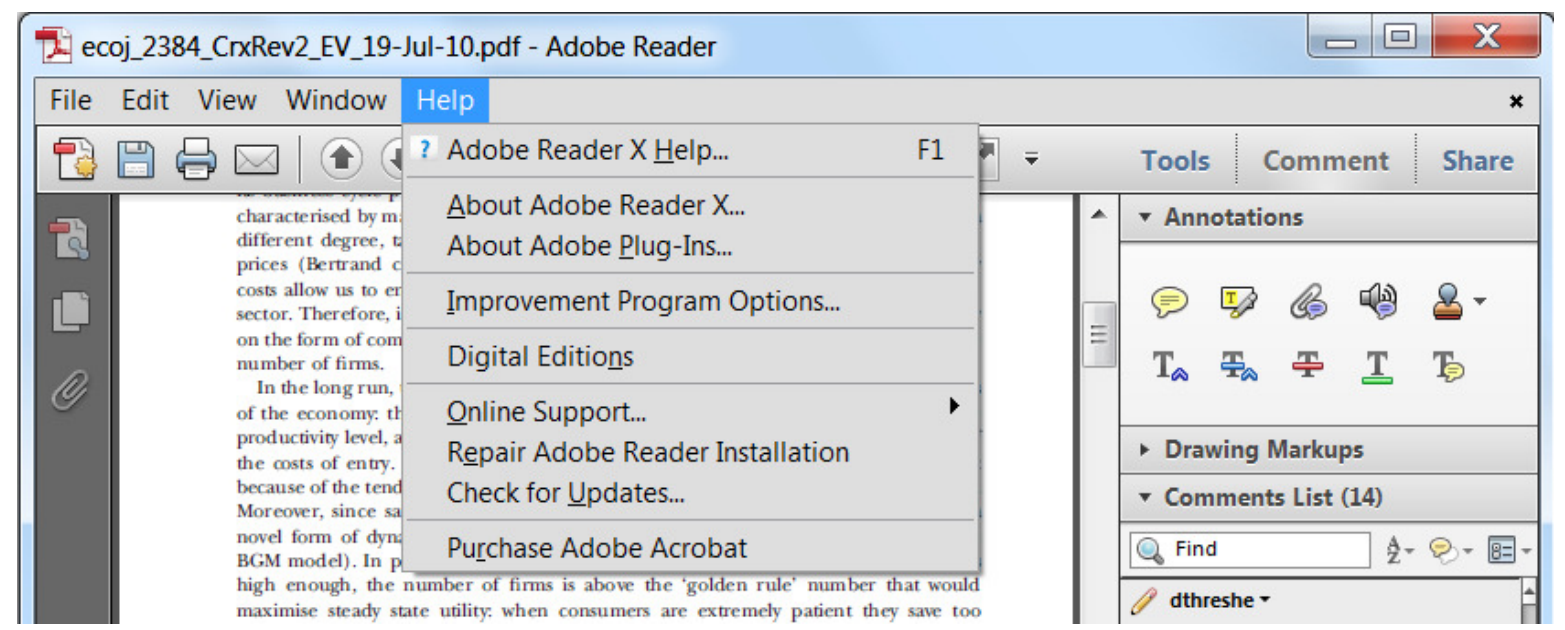

